\title{
SEDAMDESET GODINA KNJIŽNICE MARINA DRŽIĆA U ZAGREBU
}

\author{
SEVENTY YEARS OF THE MARIN DRŽIĆ \\ LIBRARY IN ZAGREB
}

Božica Dragaš

Knjižnice grada Zagreba

bozica.dragas@kgz.hr

\author{
UDK / UDC 027.022(497.5 Zagreb)(091) \\ Izvorni znanstveni rad / Original scientific paper \\ Primljeno / Received: 30. 3. 2018. \\ Prihvaćeno / Accepted: 4. 6. 2018.
}

\section{Sažetak}

Cilj. Cilj je rada ukratko prikazati 70-godišnju povijest mreže Knjižnice Marina Držića, koju čine Knjižnica Marina Držića kao središnja knjižnica te tri njezina ogranka: Dječja knjižnica Marina Držića, Knjižnica Ivana Gorana Kovačića i Knjižnica Savica. Knjižnica Marina Držića dio je mreže Knjižnica grada Zagreba.

Pristup/metodologija/dizajn. Kronološki prikaz daje se od osnutka područne knjižnice 1948. godine, kao prve narodne knjižnice na području zagrebačke četvrti Trnje, do aktualnih pokazatelja rada svih sastavnica mreže Knjižnice Marina Držića. Podaci o Knjižnici prikupljeni su u Državnom arhivu Zagreb, arhivi Knjižnice Marina Držića, stručnim radovima objavljenim o programima Knjižnice te na knjižničnim mrežnim stranicama.

Rezultati. Povijesni pregled pokazuje povezanost razvoja Knjižnice, njezina fonda, usluga i programa s društvenim, kulturnim i urbanističkim zbivanjima u lokalnoj sredini, kao i demografskom dinamikom zajednice u kojoj djeluje. U radu je vidljivo da je Knjižnica svoj knjižnični fond, usluge i programe oblikovala na osnovi praćenja potreba zajednice. Rad također upozorava na problem nedostatnosti knjižničnih prostora, koji su u Knjižnici Marina Držića znatno manji od standardima predviđenih minimuma, što ne samo da otežava ispunjavanje svih uloga koje današnja knjižnica ima nego ih dijelom i posve onemogućava.

Vjesnik bibliotekara Hrvatske 61, 1(2018), 201-217

ISSN 0507-1925

(C) VBH 2018. 
Originalnost/vrijednost. Rad je prvi kronološki prikaz povijesti Knjižnice Marina Držića te bi mogao biti polazište za iscrpnije istraživanje i podrobniji opis. S obzirom na to da o nastanku i razvoju zagrebačkih narodnih knjižnica postoji vrlo malo publiciranih radova, ovaj rad pridonosi izgradnji mozaika povijesti zagrebačkih knjižnica te može biti poticaj i nekoj drugoj knjižnici da načini sličan kronološki presjek ako ga još nema.

Ključne riječi: Dječja knjižnica Marina Držića, Knjižnica Ivana Gorana Kovačića, Knjižnica Marina Držića, Knjižnica Savica, povijest narodne knjižnice

\begin{abstract}
Purpose. The purpose of this paper is to present the 70-year-long history of the Marin Držić Library network in Zagreb, which consists of the Marin Držić Library as the district library and three branch libraries: the Marin Držić Children's Library, the Ivan Goran Kovačić Library, and the Savica Library. The Marin Držić Library is a part of the Zagreb City Libraries network
\end{abstract}

Approach/methodology/design. The chronological overview begins with the founding of the district library in 1948 as the first public library in Zagreb's district of Trnje, and ends with the current performance indicators for all four libraries in the network. The information about the Library were obtained from the State Archives in Zagreb, the Marin Držić Library archives, professional papers on the Library's programmes, and the Library's website.

Findings. The historical overview demonstrates how the Library's development, book collections, its services and programmes reflected the social, cultural, and urban planning events in the local community, as well as the demographic dynamics of the community in which the Library operates. It can be concluded from the paper that the Library formed its book collections, services and programmes by being aware and recognizing the needs of the community. The paper also points out the problem of the lack of library space, which is significantly smaller in the Marin Držić Library than the minimum stated in library space standards. This not only complicates the fulfilment of all the roles of a modern library, but also makes some of them impossible to perform.

Originality/value. The paper is the first chronological overview of the history of the Marin Držić Library and could therefore be a starting point for a more thorough research and a detailed description. Since there are very few published papers on the foundation and development of public libraries in Zagreb, this paper contributes to the creation of a mosaic of Zagreb libraries histories and could serve as an inspiration to other libraries for writing a similar chronological overview, if they do not have one already.

Keywords: history of the public library, The Ivan Goran Kovačić Library, The Marin Držić Children's Library, The Marin Držić Library, The Savica Library 


\section{Uvod}

Knjižnica Marina Držića 2018. godine obilježava 70. obljetnicu osnutka svoje središnje knjižnice. Mrežu Knjižnice Marina Držića čine istoimena središnja knjižnica ${ }^{1}$ s dislociranim Odjelom nabave i obrade te tri ogranka: Dječja knjižnica Marina Držića ${ }^{2}$, Knjižnica Ivana Gorana Kovačića ${ }^{3}$ i Knjižnica Savica. ${ }^{4}$ Od 2007. godine Knjižnica je u sastavu mreže Knjižnica grada Zagreba, čime je središnja knjižnica Knjižnice Marina Držića postala područna.

Svih pet lokacija nalazi se u zagrebačkoj četvrti Trnje, koja obuhvaća južni dio središnjeg prostora grada Zagreba i prostire se na 736,46 ha $\left(7,365 \mathrm{~km}^{2}\right) .{ }^{5} \mathrm{Na}$ sjeveru željeznička pruga dijeli Trnje od Gradske četvrti Donji grad, a na jugu rijeka Sava od Novog Zagreba. Na istoku, u Heinzelovoj ulici, Trnje graniči s Peščenicom - Žitnjakom, a na zapadu, na Savskoj cesti, s Trešnjevkom. Prema popisu stanovništva iz 2011. godine, četvrt ima 42282 stalna stanovnika. ${ }^{6}$

Sedamdeset godina Knjižnice Marina Držića neraskidivo je povezano s društvenim, urbanističkim i kulturološkim zbivanjima u Trnju ${ }^{7}$, tijekom kojih se ono intenzivno preobrazilo iz nekoć ruralne i periferne sredine $u$ današnje šire gradsko središte sa snažnim obrazovnim, poslovnim i javnim sadržajima. ${ }^{8}$

Nekoć kmetsko selo, s gradom je bilo povezano samo jednom cestom, Med Grabami (današnjom Petrinjskom cestom). ${ }^{9}$ Danas kroz Trnje prolaze tri ključne zagrebačke prometnice: Slavonska avenija, Ulica grada Vukovara i Avenija Marina Držića, a omeđuju ga još dvije vitalne zagrebačke ceste: Savska cesta na zapadu i Heinzelova na istoku. Danas je na Trnju nekoliko visokourbaniziranih naselja novogradnji, primjerice Cvjetno naselje, Kruge, Kanal, Martinovka, Savica, Sigečica, Veslačko naselje, Vrbik. U četvrti je smješten velik broj visokoškolskih ustanova: Fakultet elektrotehnike i računarstva, Filozofski fakultet, Fakultet strojarstva i brodogradnje, Učiteljski fakultet, Nacionalna i sveučilišna knjižnica. Na

1 Knjižnice grada Zagreba. Knjižnica Marina Držića. [citirano: 2018-23-03]. Dostupno na: http://www.kgz.hr/hr/knjiznice/knjiznica-marina-drzica/79.

2 Knjižnice grada Zagreba. Dječja knjižnica Marina Držića. [citirano: 2018-23-03]. Dostupno na: http://www.kgz.hr/hr/knjiznice/djecja-knjiznica-marina-drzica/59.

3 Knjižnice grada Zagreba. Knjižnica Ivana Gorana Kovačića. [citirano: 2018-23-03]. Dostupno na: http://www.kgz.hr/hr/knjiznice/knjiznica-ivana-gorana-kovacica/73.

${ }^{4}$ Knjižnice grada Zagreba. Knjižnica Savica. [citirano: 2018-23-03]. Dostupno na: http://www. $\mathrm{kgz.hr} / \mathrm{hr} / \mathrm{knjiznice/knjiznica-savica/65.}$

5 Grad Zagreb: službene stranice. [citirano: 2018-23-03]. Dostupno na: https://www.zagreb.hr/ osnovni-podaci/14164.

6 Isto.

7 Maroević, I. Zagreb njim samim. Zagreb: Durieux, 1999. Str. 109-139.

8 Urbanistički zavod grada Zagreba. Trnje: idejno urbanističko rješenje. Zagreb: Urbanistički zavod grada Zagreba, 1965.

9 Grad Zagreb: službene stranice : iz povijesti. [citirano: 2018-23-03]. Dostupno na: https:// www.zagreb.hr/iz-povijesti/14165. 
Trnju su također Autobusni kolodvor, Gradsko poglavarstvo, Koncertna dvorana Vatroslava Lisinskog, Općinski građanski sud i Pučko otvoreno učilište.

Ovim se radom daje kratak kronološki prikaz 70-godišnje povijesti Knjižnice Marina Držića, od osnutka područne knjižnice 1948. godine, kao prve narodne knjižnice na području zagrebačke četvrti Trnje, do aktualnih pokazatelja rada svih sastavnica mreže Knjižnice Marina Držića. Podaci su prikupljeni u Državnom arhivu Zagreb, arhivi Knjižnice Marina Držića, stručnim radovima objavljenim o programima Knjižnice te na knjižničnim mrežnim stranicama.

\section{Prve narodne knjižnice na Trnju: 1946.-1960.}

Začeci Knjižnice Marina Držića datiraju u 1946. godinu, kada se spominje prva trnjanska knjižnica kao dio Doma kulture „Ivan Goran Kovačić“, kako je to i zamišljeno na prvoj konferenciji rajonskih pročelnika prosvjetnih odjela održanoj 11. srpnja $1945 .^{10}$

„Ti domovi imaju biti žarišta čitavog kulturnog prosvjetnog života. U njima treba stajati sva tekuća štampa, a ako nema drugih prostorija, također i knjižnica, te rekviziti za diletantske, pjevačke, šahovske i druge sekcije.“

Dvije godine poslije, 10. srpnja 1948., ta je knjižnica otvorena kao samostalna ustanova pod nazivom Narodna knjižnica i čitaonica „Trnje“. ${ }^{11} \mathrm{O}$ uvjetima u kojima je radila najbolje svjedoči opis iz „Izvještaja o stanju knjižnica na području grada Zagreba“. ${ }^{12}$

„Knjižnica IV. rajona u Trnjanskoj cesti br. 36 smještena je u prizemlju Doma kulture 'Ivan Goran Kovačić'. Prostorije su nehigijenske, hladne i neuređene. Namještaj je vlasništvo društva 'Ivan Goran Kovačić' pa osim polica, knjiga i svjetiljke, knjižnica ne posjeduje ništa od vlastitog namještaja.“

10 Državni arhiv u Zagrebu. Narodni odbor grada Zagreba 1945.-1963.: Odjel za prosvjetu i kulturu. Zapisnici sjednica kolegija u Odjelu (za gimnazije, stručno školstvo te kulturu i umjetnost) Gradskog prosvjetnog aktiva, međurajonskih konferencija pročelnika prosvjetnih odjela, te raznih sastanaka : 1945-1953. Prva skupna konferencija rajonskih pročelnika prosvjetnih odjela u Prosvjetnom odjelu gradskog N.O.O.-u. 11. srpnja [1945.].

11 Državni arhiv u Zagrebu. Narodni odbor grada Zagreba 1945.-1963.: Odjel za prosvjetu i kulturu. Općenito o djelatnosti Odsjeka za narodno prosvjećivanje: 1946-1955. Podaci o kulturno-prosvjetnoj djelatnosti na području IV. rajona.

12 Državni arhiv u Zagrebu. Narodni odbor grada Zagreba 1945.-1963.: Odjel za prosvjetu i kulturu. Planovi rada i izvještaji knjižnica; dosjei Gradske knjižnice i Zagrebačkog knjižničarskog poduzeća: 1945.-1949. Izvještaj o stanju knjižnica na području grada Zagreba. 
Knjižnica je rad započela s fondom koji je obuhvaćao oko 1500 knjiga i do kraja 1948. godine imala je 200 članova. ${ }^{13}$ Već sljedeće godine imat će 3978 knjiga te 927 članova, koji su posudili 124563 knjige. ${ }^{14}$ Unatoč krajnje nepovoljnim radnim uvjetima, osim posudbe knjiga, trnjanska knjižnica organizira brojne književne „diskusije“ i ,čitalačke grupe“. U Izvještaju Knjižnice za razdoblje od 11. prosinca 1949. do 17. travnja 1950. navodi se da je održano deset diskusija vezanih uz književnike i njihova djela (Vladimir Nazor, Ivan Cankar, Aleksandr Sergejevič Puškin, Ivan Goran Kovačić, Stevan Sremac, Borislav Stanković, Honoré de Balzac, Ivo Andrić, Branko Ćopić), dok su dvije diskusije tematizirale rad knjižnice: „Značenje i rad knjižnice“ i „Diskusija o potrebama knjižnice i željama čitača“" ${ }^{15}$ Osim diskusija, u istom razdoblju održana je dvadeset jedna čitalačka grupa, pretežno s temama iz suvremene književnosti, a na njima je sudjelovalo ukupno 246 posjetitelja. Za navedeno razdoblje postoji i izvješće o radu u dvama tzv. tjednima prosvjećivanja, u kojem se primjerice u opisu prve diskusije koja je održana u prvom tjednu prosvjećivanja navodi da je referat o Vladimiru Nazoru održala studentica agronomije, o „Medvjedu Brundu“ govorila je i odlomak recitirala učenica V. gimnazije, a događaju je prisustvovalo „pet kućanica, tri studenta, šest studentica, četiri radnice i dva pionira". ${ }^{16}$

Godine 1958. Knjižnica „Trnje“ seli se u novouređene prostore u Trnjanskoj cesti 35, dok će kuća u kojoj je dotad bila smještena, zajedno s nekoliko susjednih objekata, uskoro biti srušena zbog gradnje Općinskog suda u Zagrebu, tzv. Palače pravde.

Sredinom 1950-ih na Trnju su otvorene još dvije narodne knjižnice. Godine 1955. na Dubravkinu trgu, u prostorijama Mjesne zajednice, otvorena je Knjižnica „Kanal - Sigečica“, a Knjižnica „Ivan Goran Kovačić“" otvorena je 1957. u današnjoj Ulici grada Vukovara 35, u novoizgrađenoj stambenoj zgradi arhitekta Drage Galića $^{17}$, koja je danas zaštićeno kulturno dobro. ${ }^{18}$

13 Državni arhiv u Zagrebu. Narodni odbor grada Zagreba 1945.-1963.: Odjel za prosvjetu i kulturu. Općenito o djelatnosti Odsjeka za narodno prosvjećivanje: 1946-1955. Podaci o kulturno-prosvjetnoj djelatnosti na području IV. rajona.

14 Isto.

15 Državni arhiv u Zagrebu. Narodni odbor grada Zagreba 1945.-1963.: Odjel za prosvjetu i kulturu. Općenito o djelatnosti Odsjeka za narodno prosvjećivanje: 1946-1955. Izvještaj knjižnice IV. rajona „Trnje“ u Zagrebu od 11. XII. 1949. do 17. IV. 1950.

16 Državni arhiv u Zagrebu. Narodni odbor grada Zagreba 1945.-1963.: Odjel za prosvjetu i kulturu. Općenito o djelatnosti Odsjeka za narodno prosvjećivanje: 1946-1955. Izvještaj o radu knjižnice IV. rajona „Trnje“ u tjednu prosvjećivanja od 11-19. XII. 1949 i od 9-17. IV. 1950. godine.

17 Maroević, I. Antologija zagrebačke arhitekture. Zagreb: Art studio Azinović, 2003. Str. 165-167.

18 Galerija nepokretnih kulturnih dobara Grada Zagreba. [citirano: 2018-23-03]. Dostupno na: http://www1.zagreb.hr/zagreb/galerijakd.nsf/VO/1E7203B2236BC646C1257F3E00492F72?OpenDocument. 
Te godine na Aveniji Marina Držića 10 niče i prvi trnjanski neboder. ${ }^{19} \mathrm{U}$ njemu će se 1959. otvoriti Knjižnica i čitaonica "Marin Držićc, u koju se tada seli i knjižnica s Dubravkina trga. U novom prostoru knjižnica ima čitaonicu, odjel za odrasle i odjel za djecu, što tada imaju samo malobrojne zagrebačke knjižnice. U izvješću iz 1957. godine „O radu i problemima knjižnica i čitaonica na području grada Zagreba“" navodi se da na užem području grada radi deset općinskih knjižničnih mreža (Gradska knjižnica, Radnička knjižnica, Donji grad, Gornji grad, Trešnjevka, Maksimir, Medveščak, Trnje, Črnomerec, Peščenica) s ukupno sedamnaest narodnih knjižnica, među kojima su samo tri dječje knjižnice (Gornji grad, Ribnjak, Črnomerec) i jedan dječji odjel (u Gradskoj knjižnici). ${ }^{20}$

\section{Narodna biblioteka „Marin Držićc: 1961.-2007.}

Godine 1961., na temelju zaključka Općinske skupštine Trnje od 16. ožujka, tri trnjanske narodne knjižnice - Narodna knjižnica i čitaonica „Trnje“ (osnovana 1948.), Knjižnica „Ivan Goran Kovačić“ (osnovana 1957.) te Knjižnica i čitaonica "Marin Držićc" (osnovana 1959.) - udružuju se pod nazivom Narodna biblioteka „Marin Držićc. 21

Godine 1967. Knjižnica „Trnje“ seli se iz Trnjanske 35 u novi prostor, u današnju Ulicu grada Vukovara $222^{22}$, u prizemlje zgrade koja je danas također zaštićeno kulturno dobro. ${ }^{23} \mathrm{U}$ skučenih 99 četvornih metara Knjižnica se nalazi i danas, kao središnja knjižnica mreže Knjižnice Marina Držića.

U to vrijeme Narodna biblioteka „Marin Držićc koordinira rad svih knjižnica na terenu, školskih i sindikalnih. Sve do početka 1990-ih zaduženi djelatnici jedanput tjedno odlaze u knjižne stanice u tvornicama i ustanovama koje rade $u$ lokalnoj sredini. ${ }^{24}$ Naime brojne sindikalne knjižnice na području Trnja aktivne su još od sredine 1940-ih, i prije nego što je na tom području osnovana narodna knjižnica - u prvom tromjesečnom izvješću o knjižnicama 1948. godine navodi se jedanaest takvih sindikalnih podružnica („Croatia“, „Ivančica“, „Ložiona“, „Paromlin“, „Perunika“, „Plinara“, „Pobjeda“, „Radiona“, „Tvornica papira“, „,Ventilator“, „Vinko Jeđut"). Tako primjerice 1983. godine Biblioteka „Marin Držic““

\footnotetext{
19 Damjanović, D. Zagreb: arhitektonski atlas. Zagreb: AGM, 2014. Str. 328.

20 Državni arhiv u Zagrebu. Narodni odbor grada Zagreba 1945.-1963.: Odjel za prosvjetu i kulturu. Zapisnici sjednica kolegija u Odjelu (za gimnazije, stručno školstvo te kulturu i umjetnost) Gradskog prosvjetnog aktiva, međurajonskih konferencija pročelnika prosvjetnih odjela, te raznih sastanaka: 1945.-1963. O radu i problemima knjižnica i čitaonica na području grada Zagreba.

${ }^{21}$ Arhiva Knjižnice Marina Držića. Izvještaj o poslovanju Biblioteke „Marin Držić““ u 1966. godini.

22 Damjanović, D. Nav. dj, str. 327.

23 Galerija nepokretnih kulturnih. Nav. dj.

24 Arhiva Knjižnice Marina Držića. Izvještaji o radu tvorničkih knjižnica. 1972. -1975.
} 
ima knjižnu stanicu u sedam radnih organizacija: „Chromos-Mirisi“, „Jadran“, „Janko Gredelj“, „Kutrilin“, „Opće vodoprivredno poduzeće za vodno područje sliva Save“, „Tehnika“, „Ventilator“. U njima je te godine upisano 1856 članova, koji su posudili 13069 jedinica građe..$^{25}$

Osim tjednih odlazaka u tvorničke knjižne stanice i koordiniranja njihova rada, Biblioteka „Marin Držić“ njihovim je članovima omogućavala besplatno korištenje cjelokupnim knjižnim fondom i ostalim knjižničnim uslugama. Drugi način približavanja knjige radnicima i službenicima ostvarivao se kroz mogućnost kolektivnog upisa preko sindikalnih organizacija, čime je u ruke potencijalnog korisnika dolazila gotova članska iskaznica. Primjerice 1983. godine na taj je način upisano 580 radnika i službenika („Dalekovod“, „Ina trgovina“, „Ingra“, „Elektroprenos“, Institut za elektroprivredu, Republički sekretarijat unutrašnjih poslova i Skupština općine Trnje). ${ }^{26}$

$\mathrm{Za}$ izvanredan doprinos u približavanju knjige radnicima Biblioteka „Marin Držić“" dobila je prvu nagradu „Pavao Markovac“ za $1966 .{ }^{27}, 1971 .{ }^{28}$ i 1983 . godi$\mathrm{nu}^{29}$, a tijekom vremena za taj je rad dobila i brojne diplome. Jedini problem koji se u knjižničnim izvještajima o radu spominje u vezi s tvorničkim knjižnim stanicama jest problem s povratom knjiga, čemu se, među ostalim, nastojalo doskočiti i stavljanjem popisa dužnika na vrata tvorničkih restorana. ${ }^{30}$

Osim u tvornicama, od sredine 1970-ih Biblioteka „Marin Držić“ ima nekoliko knjižnih stanica i u mjesnim zajednicama, u tzv. bijelim područjima bez kulturnih sadržaja. Ondje zaduženi knjižničari odlaze dva do tri puta tjedno. Primjerice 1983. godine Biblioteka ima knjižnu stanicu u četiri mjesne zajednice: „Cvjetno naselje“, „Bratstvo i jedinstvo“, „Ljubica Gerovac“ i „Stjepan Škrnjug“, u kojima je te godine upisano 808 članova i posuđeno 8719 knjiga. $^{31}$

Od 1978. godine Knjižnica Ivana Gorana Kovačića pruža stručnu podršku i knjižnici Doma za starije i nemoćne osobe „Trnje“, a ta se suradnja održala do danas, kada se kao program „Knjigom do vrata“ provodi u sklopu projekta „65 plus" . ${ }^{32}$ Poput odlazaka u tvorničke knjižnice i u knjižnice mjesnih zajednica, i odlasci u Dom „Trnje“ imaju stalni tjedni termin.

\footnotetext{
25 Arhiva Knjižnice Marina Držića. Izvještaju o radu za 1983. godinu.

26 Isto.

27 Podijeljene nagrade „Pavao Markovac“. // Vjesnik, 29. 4. 1967.

28 Prva nagrada knjižnici „Marin Držić“ u Zagrebu. // Vjesnik, 28. 4. 1972.

29 Arhiva Knjižnice Marina Držića. Izvještaj o radu za 1983. godinu.

30 Arhiva Knjižnice Marina Držića. Izvještaji o radu tvorničkih knjižnica. 1972.-1975.

31 Arhiva Knjižnice Marina Držića. Izvještaj o radu za 1983. godinu.

32 Knjižnice grada Zagreba. 65 plus. [citirano: 2018-23-03]. Dostupno na: http://www.kgz.hr/ hr/65-plus-1296/1296.
} 
Od sredine 1980-ih pa do početka 1990-ih Biblioteka ima knjižnu stanicu i u Domu učenika Željezničkog obrazovnog centra, današnje Tehničke škole Zagreb, koji je smješten u blizini središnje knjižnice mreže Knjižnice Marina Držića.

Godine 1980. „za uspješno ostvarivanje bibliotečne djelatnosti i brojne zapažene rezultate na širenju i razvijanju kulturnih aktivnosti i uspostavljanje svestranih suradnji“ Narodna biblioteka „Marin Držić“ dobila je Nagradu grada Zagreba. ${ }^{33}$

No stalni porast knjižničnoga fonda te razvoj programskih aktivnosti tijekom 1970-ih i 1980-ih godina u žarište će dovesti problem skučenih knjižničnih prostora. Naime podaci o stanovništvu Trnja pokazuju da se u razdoblju od 1953. do 1971. dogodio njegov ekspanzivni rast. Prema popisima stanovništva, 1953. godine na Trnju živi 14961 stanovnik $^{34}$, dok je 1971. godine 47686 stanovnika $^{35}$, što je trostruko više. Ta se slika odražava i u podacima o knjižničnom članstvu: 1953. godine Knjižnica „Trnje“ ima 362 člana $^{36}$, a 1971. Knjižnica ima 6188 članova $^{37}$, što je gotovo dvadesetorostruko povećanje. Najveći broj žitelja Trnja zabilježen je u Popisu stanovništva 1991., kad iznosi 51090 stanovnika. ${ }^{38}$

Godine 1988. u izvješću o stanju mreže narodnih knjižnica na Trnju te prostornim potrebama navodi se da je situacija s knjižničnim prostorom na općini Trnje alarmantna. ${ }^{39}$ Postojeći prostor obuhvaćao je 432 četvorna metra, a prema standardima, u općini s 48000 stanovnika trebao je obuhvaćati minimalno 1800 četvornih metara. ${ }^{40}$ Najkritičnije stanje bilo je, i još uvijek jest, u središnjoj jedinici, čiji ukupan prostor zauzima 99 četvornih metara, od čega pomoćne prostorije imaju samo 9 četvornih metara, dok je odlukom Odbora za bibliotečnu djelatnost

\footnotetext{
33 Narodna biblioteka „Marin Držićc“ // Delegatski list, 5, 86 (1981), str. 15.

34 Popis stanovništva 1953. Knjiga XIII. Stanovništvo i domaćinstva: podaci za naselja i dijelove naselja prema upravnoj podjeli u 1953. godini. Beograd: Savezni zavod za statistiku, 1959. Str. 184.

35 Popis stanovništva, domaćinstava, stanova i poljoprivrednih gospodarstava: 31. ožujak 1991. Stanovništvo prema narodnosti po naseljima. Zagreb: Republički zavod za statistiku, 1992. Str. 16.

36 Državni arhiv u Zagrebu. Narodni odbor grada Zagreba 1945.-1963. : Odjel za prosvjetu i kulturu. Planovi rada i izvještaji knjižnica; dosjei Gradske knjižnice i Zagrebačkog knjižničarskog poduzeća : 1945.-1949. Izvještaj o stanju knjižnica na području grada Zagreba. Izvještaj o stanju knjižnica na području grada Zagreba.

37 Arhiva Knjižnice Marina Držića. Izvještaj o poslovanju Biblioteke „Marin Držić“ u 1971. godini.

38 Popis stanovništva, domaćinstava, stanova i poljoprivrednih gospodarstava: 31. ožujak 1991. Stanovništvo prema narodnosti po naseljima. Zagreb: Republički zavod za statistiku, 1992. Str. 16.

39 Arhiva Knjižnice Marina Držića. Stanje mreže narodnih knjižnica na području općine Trnja i prostorne potrebe do 2000. godine.

40 Minimum jugoslavenskih standarda za narodne knjižnice // Vjesnik bibliotekara Hrvatske 23, 1-4(1977-1978), 218-229.
} 
od 16. listopada 1987. dogovoreni minimum knjižničnog prostora za knjižnice u gradu Zagrebu iznosio 200 četvornih metara. ${ }^{41}$

Taj nedostatak djelomice je nadomješten pomoću nekoliko adaptacija. Godine 1975. proširen je prostor galerije u Knjižnici „Ivan Goran Kovačić“, dok je prostor knjižnične čitaonice tada još uvijek u vlasništvu Mjesne zajednice. Knjižnici će biti dodijeljen tek $1980 .{ }^{42} \mathrm{U}$ središnjoj knjižnici 1979. godine adaptacijom je podignuta galerija od 33 četvorna metra, na koju se tada smješta fond stručne građe te služba nabave i obrade, koja taj posao u nekoliko četvornih metara obavlja za sve tri knjižnice u mreži. Galerija ima nepropisno nizak strop te je većim dijelom široka svega 1,2 metra ${ }^{43}$ Godine 1990. unajmljen je podrumski prostor od 50 četvornih metara, u koji je tada s galerije preselila služba nabave i obrade.

Još je u „Srednjoročnom planu razvoja bibliotečne djelatnosti USIZ-a kulture Grada Zagreba 1986-1990.“, koji je izradila Matična služba Knjižnica grada Zagreba, kao jedna od žurnih potreba na općini Trnje navedeno osiguravanje većeg prostora za središnju knjižnicu. ${ }^{44}$ Taj se plan još uvijek nije ostvario.

S obzirom na to da je u naselju Savica tijekom 1980-ih znatno povećan broj stanovnika zbog izgradnje najvećeg dijela višestambenih objekata koji čine to naselje, nametnula se potreba za otvaranjem knjižnice i u tom dijelu Trnja. U „Srednjoročnom planu razvoja bibliotečne djelatnosti USIZ-a kulture Grada Zagreba 1986-1990.“ za nju je bio predviđen prostor od 500 četvornih metara ${ }^{45}$ Knjižnica Savica, kao ogranak Narodne biblioteke Marin Držić, otvorena je 1993. godine u prostoru od 200 četvornih metara, u koji je smješten odjel za djecu i mlade, odjel za odrasle, čitaonica periodike te dva radna stola s četiri čitalačka mjesta. Prostor se nalazi u višestambenom objektu, na jednom od platoa izdignutih nekoliko metara od tla i namijenjenih samo za pješački promet, koji su specifični za to naselje, a nastali su u skladu s Le Corbusierovom idejom o razdvajanju prometnih i pješačkih prostora. U vrijeme otvorenja, Knjižnica Savica bila je jedna od malobrojnih hrvatskih knjižnica s računalno obrađenim cjelokupnim fondom.

Četiri godine poslije, 1997. godine, iz unajmljenih podrumskih prostorija u Ulici grada Vukovara 222 služba nabave i obrade preselit će se u prostranih osamdeset četvornih metara, također u naselju Savica. Podrumski će prostor tada postati spremište Knjižnice, a u toj je funkciji u najmu ostao do danas.

\footnotetext{
41 Arhiva Knjižnice Marina Držića. Stanje mreže narodnih knjižnica na području općine Trnja i prostorne potrebe do 2000. godine.

42 Isto.

43 Isto.

44 Arhiva Knjižnice Marina Držića. Srednjoročni plan razvoja bibliotečne djelatnosti USIZ-a kulture Grada Zagreba 1986-1990.

45 Isto.
} 
U „Prijedlogu mreže narodnih knjižnica na općini Trnje do 2000. godine“446, koji je izrađen 1989. godine, osim osiguravanja primjerena prostora za središnju knjižnicu koji je prema standardima ${ }^{47}$ bio predviđen na veličinu od oko 1000 četvornih metara i osim otvaranja ogranka na Savici, na jugoistočnom dijelu Trnja, kao treće najpotrebnije navodi se otvaranje ogranka u Cvjetnom naselju, na jugozapadnom dijelu Trnja. Ta bi lokacija okupljala korisnike iz Cvjetnog naselja, Veslačkog naselja i Vrbika, kao i studente iz Studentskog doma „Cvjetno naselje“. No taj prijedlog do danas nije realiziran.

Godine 1996. Narodna biblioteka „Marin Držić“ promijenila je naziv u Knjižnica Marina Držića, a od 2007. godine Knjižnica je integrirana u mrežu Knjižnica grada Zagreba.

Unatoč tomu što je na području četvrti Trnje izgrađeno nekoliko novih naselja s pretežno visokom gradnjom, od 1991. godine broj žitelja Trnja u stalnom je opadanju. ${ }^{48}$ Godine 2011. zabilježena su 42282 stalna stanovnika, što je u odnosu na broj od prije dvadeset godina manje za $17 \%{ }^{49}$ Budući da je svoj knjižnični fond, usluge i sve programske sadržaje Knjižnica Marina Držića nastojala oblikovati na osnovi praćenja demografske strukture lokalne sredine te osluškivanja potreba svojih korisnika, pad broja stanovnika nije se očitovao u broju članova Knjižnice. Zahvaljujući besplatnom upisu, 1991. godine u Knjižnicu se učlanilo 3000 članova više nego prethodne godine, ukupno $11700{ }^{50}$, što je bilo najbrojnije članstvo do tada. Godine 2011., kada se na Trnju bilježi pad stanovnika od $17 \%$ u odnosu na 1991. godinu, Knjižnica ima 12611 članova.

Što se tiče uvođenja novih tehnologija u poslovanje, s računalnom obradom knjižnične građe u Knjižnici Marina Držića započelo se 1990. godine, u knjižničnom programu Medved. Posudba je na svim lokacijama kompjutorizirana 1999., s tim da je u Knjižnici Savica posudba automatizirana od samog otvorenja, 1993. godine. Pristup internetu korisnicima je omogućen 2000. godine. Dvije godine poslije postavljene su knjižnične mrežne stranice, a 2003. godine u njih je ugrađen $\mathrm{i}$ e-katalog te je korisnicima omogućena rezervacija knjižnične građe putem elektroničke pošte.

Integracijom Knjižnice u mrežu Knjižnica grada Zagreba, informacijski sustav Medved zamijenjen je informacijskim sustavom ZaKi.

\footnotetext{
46 Arhiva Knjižnice Marina Držića. Prijedlog mreže narodnih knjižnica na općini Trnje do 2000. godine.

47 Minimum. Nav. dj.

48 Rajić, N.; T. Pejaković; S. Lončarić. Promjene općeg kretanja i osnovnih struktura Stanovništva grada Zagreba 2001.-2011. Zagreb: Gradski ured za strategijsko planiranje i razvoj grada, 2016. [citirano: 2018-23-03]. Dostupno na: http://www.zagreb.hr/UserDocsImages/arhiva/ Grad\%20Zagreb\%20Promjene\%20opceg\%20kretanja\%20(3).pdf.

49 Grad Zagreb - službene stranice. Nav. dj.

50 Izvještaj o ostvarenom programu u 1991. Arhiva Knjižnice Marina Držića.
} 


\section{Knjižnica Marina Držića na početku novog tisućljeća}

Središnju knjižnicu, u kojoj zbog skučenosti prostora postoji samo odjel za odrasle, blizina Filozofskog fakulteta usmjerila je na oblikovanje bogatog knjižnog fonda lijepe književnosti te društveno-humanističkog područja. ${ }^{51}$ Prema podacima za 2017. godinu ${ }^{52}$, njezin fond obuhvaća 40194 sveska, od kojih gotovo polovica nije u slobodnom pristupu, nego se nalazi na galeriji i u spremištu. U knjižnici nema uvjeta ni za minimalnu studijsku čitaonicu, a osobito ne za programske aktivnosti poput susreta, predavanja i radionica. Unatoč nepovoljnim radnim uvjetima, knjižnica je aktivna u raznovrsnim stručnim poslovima - od izrade anotacija i sudjelovanja u projektu „Pitajte knjižničare“ ${ }^{\text {“53 }}$ do provedbe Nacionalne kampanje za osobe s teškoćama čitanja i disleksijom „I ja želim čitati““54 te sudjelovanja u projektima „Zelena knjižnica za zeleni Zagreb“55 i „,65 plus“56. Također, u izlozima područne knjižnice redovito se postavljaju tematske i likovne izložbe.

Knjižnica u Aveniji Marina Držića 10 postala je Dječja knjižnica nakon selidbe Knjižnice „Trnje“ u novi prostor u današnjoj Ulici grada Vukovara 222 (1967. godine). U njoj se i danas provode pedagoško-animacijske aktivnosti za predškolsku i školsku djecu, čiji kontinuitet seže od 1972. godine. Od 2010. godine, osim knjižne građe korisnici mogu posuditi audio-vizualnu te elektroničku građu (zvučne knjige, animirane i igrane filmovi, edukativne kompjutorske igre). Prema podacima za 2017. godinu, njezina Audio-vizualna zbirka obuhvaća 1157 jedinica. ${ }^{57} \mathrm{U}$ knjižnici postoji i Roditeljska zbirka koja obuhvaća odabrane naslove pedagoško-psihološke literature namijenjene roditeljima.

U Knjižnici Ivana Gorana Kovačića programski sadržaji nastavljaju tradiciju te knjižnice začetu tijekom 1990-ih, kad je u svrhu promicanja knjige, poticanja čitanja i stvaranja čitalačke publike osmišljeno nekoliko iznimno posjećenih programa, usmjerenih osobito na studentsku korisničku populaciju i mlade. Naime sredinom 1990-ih održavao se ciklus književnih tribina „Klokotaru“, a početkom 2000-ih ciklus književnih susreta „Sat anatomije“ te jednako tako vrlo posjećen ciklus filmskih projekcija „Lakomo oko“.

\footnotetext{
51 Knjižnice grada Zagreba. Knjižnica Marina Držića. Nav. dj.

52 Arhiva Knjižnice Marina Držića. Izvještaj Knjižnice Marina Držića za 2017. godinu.

53 Usluga pitajte knjižničare. Projekt narodnih knjižnica. [citirano: 2018-23-03]. Dostupno na: http://www.knjiznica.hr/pitajte-knjiznicare.

54 Knjižnice grada Zagreba. „I ja želim čitati!“ Nacionalna kampanja za osobe s teškoćama čitanja i disleksijom. [citirano: 2018-23-03]. Dostupno na: http://www.kgz.hr/hr/i-ja-zelim-citati-nacionalna-kampanja-za-osobe-s-teskocama-citanja-i-disleksijom/35733.

55 Knjižnice grada Zagreba. Projekt Zelena knjižnica za zeleni Zagreb. [citirano: 2018-23-03].

Dostupno na: http://www.kgz.hr/hr/projekt-zelena-knjiznica-za-zeleni-zagreb/32340.

56 Knjižnice grada Zagreba. 65 plus. Nav. dj.

57 Arhiva Knjižnice Marina Držića. Izvještaj Knjižnice Marina Držića za 2017. godinu.
} 
Knjižnicu Savica odlikuju brojni inovativni programski sadržaji koje je razvila na poticaj korisnika ${ }^{58}$ ili u suradnji sa svojom lokalnom zajednicom - od pokretanja prvog volonterskog programa u Knjižnicama grada Zagreba (2004. godine) i pružanja podrške osjetljivim skupinama korisnika do aktivnog sudjelovanja u provedbi ideja tranzicijskog pokreta u svrhu podizanja kvalitete socijalnog, ekološkog i kulturnog života u lokalnoj sredini. ${ }^{59}$ Radionice informatičkog opismenjavanja osoba zrelije životne dobi te kreativne likovne radionice, također namijenjene starijim korisnicima, koje su u Knjižnici Savica pokrenute početkom 2000-ih, danas se u sklopu projekta „65 plus“ provode u dvadesetak knjižnica mreže Knjižnica grada Zagreba. ${ }^{60}$ Jednako tako, u dvadesetak knjižnica mreže provodi se i projekt „Zelena knjižnica za zeleni Zagreb“61, koji je također potekao iz Knjižnice Savica. ${ }^{62}$

Dok se u Knjižnici Savica projekt „65 plus“ danas provodi „Informatičkom radionicom za zreliju životnu dob“, kreativnom likovnom radionicom „Slikosat“, „Engleskim za polaznike zrelije dobi“, vježbaonicom „Uvod u kundalini-jogu“ te likovnim izložbama radova autora zrelije dobi, u Knjižnici Ivana Gorana Kovačića taj se projekt provodi „Informatičkim kutkom za seniore“ te prethodno spomenutim programom „Knjigom do vrata“, u sklopu kojega knjižničari jedanput tjedno odlaze u knjižni stacionar Doma za starije i nemoćne osobe „Trnje“.

Osim u Knjižnici Savica, gdje su njime obuhvaćeni korisnici svih dobnih skupina, projekt „Zelena knjižnica za zeleni Zagreb“ provodi se i u područnoj knjižnici te u Dječjoj knjižnici Marina Držića.

Dugi niz godina u dvama ograncima aktivno se provode inkluzivni programi, osobito u sklopu projekta „Knjižnica širom otvorenih vrata“ ${ }^{63}$ U Dječjoj knjižnici od 2014. godine takav se program provodi i u suradnji s udrugom „Psi pomagači“, koja educira i certificira voditelje i njihove pse pomagače u svrhu uključivanja u terapijske i odgojno-obrazovne aktivnosti za potrebe različitih korisnika. U Knjižnici Savica u sklopu projekta „Knjižnica širom otvorenih vrata“ osmišljen je

58 Dragaš, B.; S. Ercegovac. Inspirativni korisnik u inovativnoj knjižnici: iskustvo Knjižnice Savica. // Novi uvez: glasilo Zagrebačkoga knjižničarskog društva 15, 27/2(2017), 11-13. [citirano: 2018-23-03]. Dostupno na: https://zkd.hr/wp-content/uploads/sites/78/2017/09/Novi-uvez-27-2. pdf.

59 Dragaš, B.; S. Ercegovac. Potrebe lokalne zajednice i inovativni knjižnični programi:iskustvo Knjižnice Savica. // Inovativna knjižnica u službi lokalne zajednice: zbornik radova. Zagreb: Hrvatsko knjižničarsko društvo, 2017. Str. 106-124.

60 Knjižnice grada Zagreba. 65 plus. Nav. dj.

61 Knjižnice grada Zagreba. Projekt Zelena knjižnica. Nav. dj.

62 Dragaš, B.; S. Ercegovac. Program Zelena knjižnica u Knjižnici Savica: ishodište istoimenoga projekta Knjižnica grada Zagreba. // HKD Novosti 73(2017). [citirano: 2018-23-03]. Dostupno na: https://www.hkdrustvo.hr/hkdnovosti/clanak/1336.

63 Knjižnice grada Zagreba. Knjižnica širom otvorenih vrata. [citirano: 2018-23-03]. Dostupno na: http://www.kgz.hr/hr/knjiznica-sirom-otvorenih-vrata-5993/5993. 
ciklus psiholoških i pedagoških radionica „Da, mogu!“, u svrhu dodatne edukacijsko-rehabilitacijske podrške djeci i mladima s teškoćama u razvoju, a provodi se od 2016. godine.

Osim navedenih projekata, koji se uz financijsku podršku Grada Zagreba provode na razini čitave mreže Knjižnica grada Zagreba, u Knjižnici Marina Držića od ove se godine provode i zasebni projekti, također uz sufinanciranje sredstvima Grada Zagreba: „Na Trnju sa zvijezdama“ projekt je usmjeren na književne susrete s dobitnicima književnih nagrada, a provodi se u Dječjoj knjižnici Marina Držića, Knjižnici Ivana Gorana Kovačića i Knjižnici Savica; projekt „A(r)testirani““ usmjeren je na mlađu publiku i književne susrete s mladim autorima, dok „Pričaj mi o njoj“ obuhvaća ciklus radionica kojima se razvija kritičko čitanje, a bavi se društveno relevantnim temama o kojima pišu žene - ta se dva projekta provode u Knjižnici Ivana Gorana Kovačića.

I na odjelima za djecu i na odjelima za odrasle održavaju se brojne aktivnosti u stalnim tjednim, dvotjednim ili mjesečnim terminima. Primjerice na Odjelu za djecu u Knjižnici Ivana Gorana Kovačića tijekom ove godine stalni tjedni termin imaju radionica iz osnova programiranja „Kako razmišljati kao programer“, radionica „Engleski kroz priče“ te „Kreativni svijet priča“.

U Knjižnici Savica na odjelu za djecu stalni tjedni termin imaju aktivnosti za predškolsku djecu „Pričaonica“ i igraonica „Medo“, potom aktivnosti za mlade „Robotika“ i radionica modernih društvenih igara „Zmajevanje“ te čitateljski klub „Knjigoznanac“. Na odjelu za odrasle stalne su aktivnosti kreativna radionica pisanja „Coprničje pero“ te Grupa za potporu dojenja i roditeljstva „Maštoviti anđeli“".

U Dječjoj knjižnici Marina Držića stalne su aktivnosti za predškolce „Pričaonica“ i „Kutić za najmlađe“, a za školsku djecu „Maštaonica“ te čitateljski klub „Knjigotron“. Tjedni termin ima i „Igranje“, radionica modernih društvenih igara.

Prema podacima za 2017. godinu, Knjižnica Marina Držića ima 13000 članova, 112000 svezaka knjiga i 1500 jedinica audio-vizualne i elektroničke građe, od čega su prošle godine članovi posudili 140000 jedinica građe. ${ }^{64}$ Tijekom godine održano je približno 660 aktivnosti za djecu na kojima je sudjelovalo 6800 posjetitelja, dok je na odjelima za odrasle održano 90 susreta, predavanja i radionica, kojima je prisustvovalo 870 posjetitelja. Također su održane 32 tematske i 23 likovne izložbe.

Na pet lokacija Knjižnice (Knjižnica Marina Držića - Odjel za odrasle, Dječja knjižnica Marina Držića, Knjižnica Ivana Gorana Kovačića, Knjižnica Savica, Odjel nabave i obrade) zaposleno je ukupno trideset djelatnika, od kojih je šesnaest diplomiranih knjižničara, jedanaest pomoćnih knjižničara i tri spremačice.

${ }^{64}$ Arhiva Knjižnice Marina Držića. Izvještaj Knjižnice Marina Držića za 2017. godinu. 
I danas je najveći problem mreže Knjižnice Marina Držića nedostatnost prostora. Ukupna površina svih pet lokacija Knjižnice Marina Držića iznosi 712 četvornih metara, dok bi prema Standardima za narodne knjižnice u Republici Hrvatskoj u odnosu na broj stanovnika lokalne zajednice minimalna površina trebala iznositi 1480 četvornih metara. ${ }^{65}$ Prema kriteriju jedinica knjižnične građe, Knjižnica Marina Držića za posudbeni bi odjel prema Standardima trebala imati minimalno 1680 četvornih metara, što je trostruko više od postojećih 550 četvornih metara prostora namijenjenog korisnicima. ${ }^{66}$

\section{Zaključak}

Knjižnica Marina Držića mreža je knjižnica u sastavu Knjižnica grada Zagreba, koja je nastala i razvijala se na području zagrebačke gradske četvrti Trnje, pri čemu je svoj knjižnični fond, usluge i programe gradila u skladu s potrebama svoje lokalne zajednice, prateći kulturološke, društvene, urbanističke i demografske tokove u svojoj sredini. Središnja je knjižnica, pod nazivom Narodna knjižnica i čitaonica „Trnje“, osnovana 1948. godine, kada se osamostalila knjižnica koja je od 1946. postojala u sastavu Doma kulture „Ivan Goran Kovačićc. Njoj su se 1961. godine pridružile Narodna biblioteka „Marin Držić“ (osnovana 1948.) i Knjižnica „Ivan Goran Kovačićc" (osnovana 1957.) te je nova ustanova dobila naziv Narodna biblioteka „Marin Držićc“. Najmlađi ogranak, Knjižnica Savica, otvoren je 1993. godine.

Osim kontinuirane usredotočenosti na promicanje knjige i čitanja, Knjižnica provodi raznovrsne programe u svrhu potpore ranjivim i socijalno osjetljivim korisničkim skupinama, kao i programe promicanja održivog razvoja te poticanja sugrađana na aktivizam.

Kada bi knjižnični prostori barem približno dosegnuli Standardima preporučeni minimum, Knjižnica Marina Držića sa svojim bogatim knjižničnim fondom, raznovrsnim uslugama i inventivnim programskim sadržajima mogla bi postati središtem kulturnog života svoje zajednice te „treći prostor“ za sve dobne skupine svojih korisnika.

65 Standardi za narodne knjižnice u Republici Hrvatskoj. // Narodne novine 58, 1071(1999). [citirano: 2018-23-03]. Dostupno na: https://narodne-novine.nn.hr/clanci/sluzbeni/1999_06_58_1071. html.

66 Isto. 


\section{LITERATURA}

Arhiva Knjižnice Marina Držića. Izvještaj Knjižnice Marina Držića za 2017. godinu.

Arhiva Knjižnice Marina Držića. Izvještaj o ostvarenom programu u 1991.

Arhiva Knjižnice Marina Držića. Izvještaj o poslovanju Biblioteke „Marin Držić“ u 1966. godini.

Arhiva Knjižnice Marina Držića. Izvještaj o poslovanju Biblioteke „Marin Držić“ u 1971. godini.

Arhiva Knjižnice Marina Držića. Izvještaju o radu za 1983. godinu.

Arhiva Knjižnice Marina Držića. Izvještaji o radu tvorničkih knjižnica. 1972.-1975.

Arhiva Knjižnice Marina Držića. Prijedlog mreže narodnih knjižnica na općini Trnje do 2000. godine.

Arhiva Knjižnice Marina Držića. Srednjoročni plan razvoja bibliotečne djelatnosti USIZ-a kulture Grada Zagreba 1986-1990.

Arhiva Knjižnice Marina Držića. Stanje mreže narodnih knjižnica na području općine Trnja i prostorne potrebe do 2000. godine.

Damjanović, D. Zagreb: arhitektonski atlas. Zagreb: AGM, 2014.

Dragaš, B.; S. Ercegovac. Inspirativni korisnik u inovativnoj knjižnici: iskustvo Knjižnice Savica. // Novi uvez: glasilo Zagrebačkoga knjižničarskog društva 15, 27/2(2017), 11-13. [citirano: 2018-23-03]. Dostupno na: https://zkd.hr/wp-content/ uploads/sites/78/2017/09/Novi-uvez-27-2.pdf.

Dragaš, B.; S. Ercegovac. Potrebe lokalne zajednice i inovativni knjižnični programi: iskustvo Knjižnice Savica. // Inovativna knjižnica u službi lokalne zajednice: zbornik radova. Zagreb: Hrvatsko knjižničarsko društvo, 2017.

Dragaš, B.; S. Ercegovac. Program Zelena knjižnica u Knjižnici Savica: ishodište istoimenoga projekta Knjižnica grada Zagreba. // HKD Novosti 73(2017). [citirano: 2018-23-03]. Dostupno na: https://www.hkdrustvo.hr/hkdnovosti/clanak/1336.

Državni arhiv u Zagrebu. Narodni odbor grada Zagreba 1945.-1963.: Odjel za prosvjetu i kulturu. Općenito o djelatnosti Odsjeka za narodno prosvjećivanje : 1946 -1955. Izvještaj knjižnice IV. rajona „Trnje“ u Zagrebu od 11. XII. 1949. do 17. IV. 1950.

Državni arhiv u Zagrebu. Narodni odbor grada Zagreba 1945.-1963.: Odjel za prosvjetu i kulturu. Općenito o djelatnosti Odsjeka za narodno prosvjećivanje : 1946-1955. Izvještaj o radu knjižnice IV. rajona „Trnje“ u tjednu prosvjećivanja od 11-19. XII. 1949 i od 9-17. IV. 1950. godine.

Državni arhiv u Zagrebu. Narodni odbor grada Zagreba 1945.-1963.: Odjel za prosvjetu i kulturu. Općenito o djelatnosti Odsjeka za narodno prosvjećivanje : 1946-1955. Podaci o kulturno-prosvjetnoj djelatnosti na području IV. rajona. 
Državni arhiv u Zagrebu. Narodni odbor grada Zagreba 1945.-1963.: Odjel za prosvjetu i kulturu. Planovi rada i izvještaji knjižnica; dosjei Gradske knjižnice i Zagrebačkog knjižničarskog poduzeća : 1945. -1949. Izvještaj o stanju knjižnica na području grada Zagreba.

Državni arhiv u Zagrebu. Narodni odbor grada Zagreba 1945.-1963.: Odjel za prosvjetu i kulturu. Zapisnici sjednica kolegija u Odjelu (za gimnazije, stručno školstvo te kulturu i umjetnost) Gradskog prosvjetnog aktiva, međurajonskih konferencija pročelnika prosvjetnih odjela, te raznih sastanaka : 1945.-1963. O radu i problemima knjižnica i čitaonica na području grada Zagreba.

Državni arhiv u Zagrebu. Narodni odbor grada Zagreba 1945.-1963.: Odjel za prosvjetu i kulturu. Zapisnici sjednica kolegija u Odjelu (za gimnazije, stručno školstvo te kulturu i umjetnost) Gradskog prosvjetnog aktiva, međurajonskih konferencija pročelnika prosvjetnih odjela, te raznih sastanaka : 1945-1953. Prva skupna konferencija rajonskih pročelnika prosvjetnih odjela u Prosvjetnom odjelu gradskog N.O.O.-u. 11. srpnja [1945.].

Galerija nepokretnih kulturnih dobara Grada Zagreba. [citirano: 2018-23-03]. Dostupno na: http://www1.zagreb.hr/zagreb/galerijakd.nsf.

Grad Zagreb: službene stranice. [citirano: 2018-23-03]. Dostupno na: https://www.zagreb.hr

Knjižnice grada Zagreba. Dječja knjižnica Marina Držića. [citirano: 2018-23-03]. Dostupno na: http://www.kgz.hr/hr/knjiznice/djecja-knjiznica-marina-drzica/59.

Knjižnice grada Zagreba. „I ja želim čitati!“‘ Nacionalna kampanja za osobe s teškoćama čitanja i disleksijom. [citirano: 2018-23-03]. Dostupno na: http://www.kgz.hr/ $\mathrm{hr} / \mathrm{i}$-ja-zelim-citati-nacionalna-kampanja-za-osobe-s-teskocama-citanja-i-disleksijom/35733.

Knjižnice grada Zagreba. Knjižnica Ivana Gorana Kovačića. [citirano: 2018-23-03]. Dostupno na: http://www.kgz.hr/hr/knjiznice/knjiznica-ivana-gorana-kovacica/73.

Knjižnice grada Zagreba. Knjižnica Marina Držića. [citirano: 2018-23-03]. Dostupno na: http://www.kgz.hr/hr/knjiznice/knjiznica-marina-drzica/79.

Knjižnice grada Zagreba. Projekt Zelena knjižnica za zeleni Zagreb. [citirano: 201823-03]. Dostupno na: http://www.kgz.hr/hr/projekt-zelena-knjiznica-za-zeleni-zagreb/32340.

Knjižnice grada Zagreba. Knjižnica Savica. [citirano: 2018-23-03]. Dostupno na: http:// www.kgz.hr/hr/knjiznice/knjiznica-savica/65.

Knjižnice grada Zagreba. 65 plus. [citirano: 2018-23-03]. Dostupno na: http://www.kgz. $\mathrm{hr} / \mathrm{hr} / 65$-plus-1296/1296.

Knjižnice grada Zagreba. Knjižnica širom otvorenih vrata. [citirano: 2018-23-03]. Dostupno na: http://www.kgz.hr/hr/knjiznica-sirom-otvorenih-vrata-5993/5993.

Maroević, I. Antologija zagrebačke arhitekture. Zagreb : Art studio Azinović, 2003. 
Maroević, I. Zagreb njim samim. Zagreb : Durieux, 1999.

Minimum jugoslavenskih standarda za narodne knjižnice. // Vjesnik bibliotekara Hrvatske 23, 1-4(1977-1978), 218-229.

Narodna biblioteka „Marin Držić““. // Delegatski list, 5, 86 (1981), 15.

Popis stanovništva, domaćinstava, stanova i poljoprivrednih gospodarstava: 31 . ožujak 1991. Stanovništvo prema narodnosti po naseljima. Zagreb: Republički zavod za statistiku, 1992.

Popis stanovništva 1953. Knjiga XIII. Stanovništvo i domaćinstva: podaci za naselja i dijelove naselja prema upravnoj podjeli u 1953. godini. Beograd: Savezni zavod za statistiku, 1959.

Popis stanovništva, domaćinstava, stanova i poljoprivrednih gospodarstava: 31 . ožujak 1991. Stanovništvo prema narodnosti po naseljima. Zagreb: Republički zavod za statistiku, 1992.

Rajić, N.; T. Pejaković; S. Lončarić. Promjene općeg kretanja i osnovnih struktura Stanovništva grada Zagreba 2001.-2011. Zagreb: Gradski ured za strategijsko planiranje i razvoj grada, 2016. [citirano: 2018-23-03]. Dostupno na: http://www.zagreb.hr/ UserDocsImages/arhiva/Grad\%20Zagreb\%20Promjene\%20opceg\%20kretanja\%20 (3).pdf.

Standardi za narodne knjižnice u Republici Hrvatskoj. // Narodne novine 58, 1071(1999). [citirano: 2018-23-03]. Dostupno na: https://narodne-novine.nn.hr/clanci/sluzbeni/1999_06_58_1071.html.

Urbanistički zavod grada Zagreba. Trnje: idejno urbanističko rješenje. Zagreb: Urbanistički zavod grada Zagreba, 1965.

Usluga pitajte knjižničare. Projekt narodnih knjižnica. [citirano: 2018-23-03]. Dostupno na: http://www.knjiznica.hr/pitajte-knjiznicare. 